\title{
Why is Napier sea port a hot spot for invasive ants?
}

\author{
D.N.Gunawardana ${ }^{1}$, L.R. Peacock ${ }^{2}$, A.R. Flynn ${ }^{1}$, T.T. Ashcroft ${ }^{1}$ and O.R. Green ${ }^{1}$ \\ ${ }^{1}$ Ministry for Primary Industries, PO Box 2095, Auckland, New Zealand \\ ${ }^{2}$ Ministry for Primary Industries, PO Box 2926, Wellington, New Zealand \\ Corresponding author: disna.gunawardana@mpi.govt.nz
}

\begin{abstract}
Over the last 10 years the National Invasive Ant Surveillance programme, which was established in 2003 by the Ministry of Agriculture and Forestry (now Ministry for Primary Industries) in New Zealand, has resulted in a number of exotic ant detections at the Napier sea port and surrounding facilities. The surveillance is designed to detect newly established nests of exotic ant species at high risk sites around New Zealand, such as shipping ports. Potential factors contributing to exotic ant detections such as import commodity pathways and local climatic conditions in Napier were analysed. The present analysis indicates ant arrival alone or propagule pressure does not necessarily result in establishment. Abiotic factors, such as temperature and rainfall, are likely to be the main factors contributing to successful ant nest establishment at Napier sea port compared to the Ports of Auckland and Tauranga.
\end{abstract}

Keywords National Invasive Ant Surveillance, pathways, detections, exotic ants, tramp ants, air temperature, annual rainfall, Napier sea port.

\section{INTRODUCTION}

Invasive ants are considered a significant ecological and economic threat to New Zealand and are commonly intercepted at New Zealand's borders (Lester 2005; Ward et al. 2006). Increased international trade and travel increases the risk of exotic species arriving and establishing in New Zealand.

Solenopsis invicta Buren (red imported fire ant), which is considered to be one of the world's worst 100 invasive species in the world (Global Invasive Species Database 2005), was first detected in New Zealand at the Auckland International Airport in February 2001. As a result of this detection, the National Invasive Ant Surveillance programme (NIAS) was established in 2003, with the objective of detecting exotic ants early enough to prevent establishment.

The NIAS programme targets high risk sites associated with international trade and shipping, such as sea ports, international airports and container devanning sites. Since its inception in 2003, the NIAS programme has detected exotic 'tramp ant' species each season. Once detected, the nests or source of the ants are found and chemically treated. Post treatment monitoring is carried out until there is no further evidence of live ant activity.

Sea containers have long been recognised as a potential entry pathway for ants into New Zealand (Nendick et al. 2006; Ward et al. 2006). Around $65 \%$ of invasive ants detected at the New Zealand border arrive on or in empty sea containers and on commodities such as root crops from the Pacific Islands (Nendick et al. 2006).

The most effective approach to invasive ant management globally is active prevention of ant contamination not only at the entry point into a country, but also at the overseas port-of-exit where the ants originate (Hoffmann et al. 2010). 
To manage the offshore risks more effectively, the Ministry for Primary Industries (MPI) in New Zealand implemented an offshore sea container hygiene programme in 2006 to better manage sea container contamination risks (Ashcroft et al. 2008). The risk associated with root crops exported as fresh produce from the Pacific was already well managed by existing interventions.

The degree of establishment of exotic ants found at the Napier sea port, as part of the NIAS programme, has varied. Since the start of the programme at least one exotic ant species has been detected each year. As a result, a number of incursion responses were initiated at the Napier sea port to eradicate exotic ants, such as the fire ants Solenopsis invicta (in 2004) and Solenopsis geminata (in 2013).

This paper investigates why Napier sea port has had a large number of exotic ant species detected compared with other major ports, despite receiving fewer sea containers and having very low incidences of ant-contaminated containers per year. Determining the probable cause of such anomalies may increase the understanding of ant invasion pressure post-border, which in turn aids future decision-making in invasive ant management.

\section{MATERIALS AND METHODS}

Napier was compared with two other sites, Auckland and Tauranga. These two sites were chosen because they receive large numbers of containers and have a consistent history of ant detections. Three data sets were used to make the comparisons: 2003-2013 NIAS exotic ant detections, local climate data (2003-2012) and sea container imports (2005-2011).

The NIAS programme has operated every summer (December to March) since 2003. Surveillance methodology involves surveying areas within $150 \mathrm{~m}$ radius of pre-determined risk sites at sea ports, airports and transitional facilities.

The survey area is divided into $15 \times 15$ m grids. Each grid is visually inspected and a minimum of two attractant bait traps, one protein-based (sausage meat, soya oil and peanut butter) and the other sugar-based (cotton wool soaked in 30\% sugar solution), are laid close to ideal ant habitat. Surveys occur on warm sunny days between $20^{\circ} \mathrm{C}$ and $28^{\circ} \mathrm{C}$. Optimal temperatures are required to take advantage of the most favourable foraging conditions as an increase in temperature increases 'tramp ant' activity. If exotic ants are found, nests are located and eradicated.

Detection data from the periods 2003-2013 were taken from MPI's laboratory information management system database and the AsureQuality NIAS survey database.

Annual and monthly climate data for Auckland, Tauranga and Napier were extracted from NIWA's 'cliflo' database (http://cliflo.niwa.co.nz/).

As sea containers are considered a common pathway for exotic ant dispersal, sea container imports data were extracted from MPI's Quancargo database and unpublished data from MPI's Analysis and Profiling Group (2005 to 2011).

\section{RESULTS}

Since 2003 more than ten exotic ant species were detected at sea ports and transitional facilities through the NIAS programme. The most frequent detections are common tramp species, such as Paratrechina longicornis (Latreille), Tapinoma melanocephalum (Fabricius), Monomorium destructor (Jerdon) and Monomorium spp. Table 1 shows a list of tramp ant species found and the year in which the species was detected. The black crazy ant, Paratrechina longicornis (Latreille) has been detected every year. Since 2004 an undescribed Monomorium sp. belonging to the salomonis species group has become a very common detection in Auckland, Napier and Tauranga sea ports.

Two new Australian ant species Monomorium sydneyense (Forel) and Pheidole proxima (Mayr) were found to be already well established when detected in Tauranga (2003) and Napier (2004) respectively. An established population of Solenopsis invicta Buren was discovered at Napier sea port during the 2004 NIAS programme.

While the number of exotic ant detections was greater at Auckland sea port, the diversity of tramp ant species was greatest at Napier sea port (Table 2).

Rainfall and air temperature variables were examined and compared between sites. Whilst soil temperature is a good indicator of nest establishment (Vogt et al. 2003), data were not available for all locations. There are seasonal 
Table 1 Exotic tramp ant species detected annually in New Zealand through the National Invasive Ants Surveillance programme, 2003-2013 (MPI's laboratory information management system database, AsureQuality NIAS survey database).

\begin{tabular}{lccccccccccc}
\hline & \multicolumn{10}{c}{ Year detected in NIAS } \\
Tramp ant species & 03 & 04 & 05 & 06 & 07 & 08 & 09 & 10 & 11 & 12 & 13 \\
\hline Anoplolepis gracilipes & & $\bullet$ & $\bullet$ & & & $\bullet$ & & & & \\
Monomorium destructor & & & $\bullet$ & $\bullet$ & $\bullet$ & $\bullet$ & & $\bullet$ & & $\bullet$ & $\bullet$ \\
Monomorium floricola & & $\bullet$ & & & & $\bullet$ & & & $\bullet$ & & $\bullet$ \\
Monomorium spp. ${ }^{1}$ & & $\bullet$ & $\bullet$ & $\bullet$ & $\bullet$ & $\bullet$ & & $\bullet$ & $\bullet$ & $\bullet$ & $\bullet$ \\
Paratrechina longicornis & $\bullet$ & $\bullet$ & $\bullet$ & $\bullet$ & $\bullet$ & $\bullet$ & $\bullet$ & $\bullet$ & $\bullet$ & $\bullet$ & $\bullet$ \\
Solenopsis invicta & & $\bullet$ & & & & & & & & & \\
Solenopsis geminata & $\bullet$ & & & & & $\bullet$ & & & & & $\bullet$ \\
Tapinoma melanocephalum & $\bullet$ & & & $\bullet$ & & $\bullet$ & $\bullet$ & & $\bullet$ & $\bullet$ &
\end{tabular}

${ }^{1}$ Several other undescribed species of Monomorium.

Table 2 Number of exotic tramp ant detections at sea ports during NIAS 2003-2013 (MPI's laboratory information management system database, AsureQuality NIAS survey database).

\begin{tabular}{|c|c|c|c|}
\hline Ant species & Auckland & Tauranga & Napier \\
\hline A. gracilipes & 2 & & 2 \\
\hline M. destructor & & 4 & 3 \\
\hline M. floricola & & & 1 \\
\hline Monomorium spp. ${ }^{1}$ & 6 & 6 & 3 \\
\hline P. longicornis & 21 & 11 & 4 \\
\hline S. invicta & & & 1 \\
\hline S. geminata & 1 & 1 & 1 \\
\hline T. melanocephalum & 3 & 1 & 4 \\
\hline
\end{tabular}

${ }^{1}$ Several other undescribed species of Monomorium.

differences in temperature between the sites, despite the annual air temperature data showing no difference (Table 3). In general, Napier has hotter, longer summers with maximum air temperatures being on average $4^{\circ} \mathrm{C}$ warmer than Auckland and Tauranga. Napier also had more days with a maximum air temperature above $25^{\circ} \mathrm{C}$ per year (Table 3 ). Napier on average is also drier than Auckland or Tauranga, having the lowest annual total rainfall and significantly fewer wet days per year. The mean annual soil moisture deficit is also significantly higher than both Auckland and Tauranga (Table 3).
Figure 1 shows that on days where air temperatures were above $25^{\circ} \mathrm{C}$, baited pots at Napier collected more ants than the other two ports. Auckland had the lowest number of days where the maximum air temperature reached $25^{\circ} \mathrm{C}$ ( 25 days), reflecting the data indicating that less than $35 \%$ of all ants collected were on days when air temperature exceeded $25^{\circ} \mathrm{C}$ (Figure 1).

The majority of ant interceptions in New Zealand were associated with root crop imports and empty sea containers from the South Pacific region (Nendick et al. 2006). For the period 20052011, both loaded and empty sea container imports into New Zealand were predominantly discharged at Ports of Auckland and Tauranga (Figure 2). Napier port landed less than $0.001 \%$ of all loaded containers arriving in New Zealand, but received more empty containers. Historically empty containers have accounted for a large proportion of ant contamination (Nendick et al. 2006).

A comparison of ant-contaminated sea container records for the period 2005-2011, shows the Napier seaport averaged four contaminated containers per year compared to 221 at Auckland and 18 at Tauranga (C. Kingston, Ministry for Primary Industries, unpublished data).

\section{DISCUSSION}

Over the 10-year period, Napier Port recorded more diversity of exotic tramp ant species than any other port in New Zealand (eight species). 


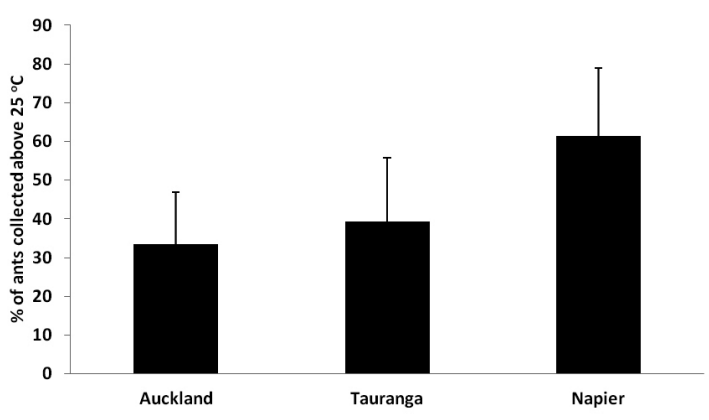

Figure 1 Percentage mean abundance of all ants caught in baited pottles at air temperatures greater than $25^{\circ} \mathrm{C}$ for the period 2006 to 2012 (95\% confidence intervals are shown) (Note: no reliable data prior to 2006).

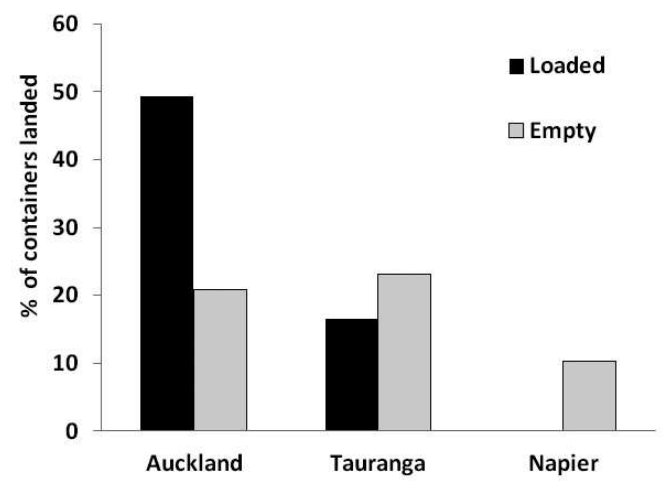

Figure 2 Percentage of all loaded and empty containers landed in New Zealand at Ports of Auckland, Tauranga and Napier for the period 2005 to 2011 (C. Kingston, Ministry for Primary Industries, unpublished data).
The number of exotic detections remained high at Napier Port in comparison with the much bigger Ports of Tauranga and Auckland, which receive significantly more containers than Napier seaport. There are potentially some detection biases with the current baiting methods with the more dominant ant species being detected (Stringer et al. 2010). However, in this study there were no major species that dominated the baited pots at the sites, and in fact, Argentine ant (Linepithema humile), which is a relatively 'good invader', did not make up a large abundance in baited pots in the study. More importantly species diversity is generally lower at ports because of the depauperate environment, with few food resources and limited diversity of habitats available, and the high degree of disturbance associated with the movement of containers and machinery. In many studies competitive exclusion has only looked at food preference but other factors such as habitat complexity and foraging ability and strategy play an important role in co-existence patterns in ant communities (Sarty et al. 2006).

One of the main factors influencing establishment of new ant species in New Zealand is likely to be species-specific responses to abiotic factors (Harris \& Barker 2007). Climatic variables, especially temperature, rainfall and humidity, play a large role in determining the distribution and establishment of ant species (Ward 2007). Temperature plays a major role in regulating ant colony foraging activity (Vogt et al. 2003; Linksvayer \& Janssen 2009). Studies have shown that maximum daily air temperature

Table 3 Climate data for the three ports for the period 2003-2012.

\begin{tabular}{|c|c|c|c|}
\hline & Auckland & Tauranga & Napier \\
\hline Mean annual air temperature $\left({ }^{\circ} \mathrm{C}\right)$ & $15.55 \pm 0.27^{1}$ & $15.17 \pm 0.28$ & $14.0 \pm 0.18$ \\
\hline Mean annual maximum air temperature $\left({ }^{\circ} \mathrm{C}\right)$ & $28.05 \pm 0.46$ & $28.83 \pm 0.87$ & $32.75 \pm 1.41$ \\
\hline Annual number of days exceeding $25^{\circ} \mathrm{C}$ & $25 \pm 5$ & $28 \pm 7$ & $38 \pm 3$ \\
\hline Mean annual total rainfall $(\mathrm{mm})$ & $1080 \pm 108$ & $1332 \pm 175$ & $872 \pm 95$ \\
\hline Annual number of wet days ${ }^{2}$ & $130 \pm 8$ & $113 \pm 5$ & $87 \pm 6$ \\
\hline Mean annual soil moisture deficit ${ }^{3}(\mathrm{~mm})$ & $57.27 \pm 8.36$ & $51.83 \pm 5.43$ & $70.88 \pm 6.66$ \\
\hline
\end{tabular}

${ }^{1} 95 \%$ confidence intervals.

${ }^{2}$ Days with $1 \mathrm{~mm}$ or more rain recorded.

${ }^{3}$ Amount of water needed to bring the soil moisture content back to field capacity, which is the amount of water the soil can hold against gravity. 
primarily determined the temporal activity of ant colonies (Harris undated). For example, maximal foraging rates for $S$. invicta occur between $22^{\circ} \mathrm{C}$ and $36^{\circ} \mathrm{C}$ (Porter 1987). Napier Port had many more days exceeding $25^{\circ} \mathrm{C}$ than other ports and had a greater proportion of ants collected when temperatures exceeded $25^{\circ} \mathrm{C}$ on survey days. This would suggest that, compared to the other two ports, at Napier Port there are more days reaching optimal temperatures conducive for foraging and ants have more opportunity to be recruited into the baited pots used during surveillance.

Temperature has a major influence on the developmental rates of ants, including oviposition and brood development (Porter 1988). Within suitable limits, higher temperatures generally result in more rapid nest growth (Hartley \& Lester 2003). Small nests that come through borders undetected can survive and develop quickly in favourable ant habitat under optimal climatic conditions.

Whilst soil temperature was not studied here, high rainfall can contribute to lower soil temperatures. If soil permeability is high in high rainfall areas, it is possible that colony establishment will be limited (Chen et al. 2002). High rainfall can restrict foraging activity (Holldobler 1990) and lower colony establishment potential (Vega \& Rust 2001) in Auckland and Tauranga. Napier was certainly much drier and has a larger seasonal soil moisture deficit than both Auckland and Tauranga. The warmer and drier conditions at Napier are likely to be more conducive to ant establishment, particularly if ant arrivals occur in the summer months. In the past there have been finds of large ant nests at Napier from species such as S. invicta, M. destructor and S. geminata. Each of these nests was estimated to contain several hundred workers, with the minimum nest age of 6 months to 1 year; such large functioning nests could only thrive under optimal climate conditions. After the initial detection in 2001 at Auckland, S. invicta was detected twice, in 2004 at Napier sea port and in 2006 at Whirinaki, $20 \mathrm{~km}$ north of Napier. Both incursions were subjects of response activities and later declared eradicated. The Whirinaki detection was not a part of the annual NIAS programme, but the pathway was almost certainly machinery from southern USA that came through Napier Port.

Roura-Pascual et al. (2011) found evidence for biotic resistance by native ant communities to invasion from other species. Given the depauperate ant fauna of New Zealand (only 11 native species and 28 established introduced species (Valentine \& Walker 1991; Ward 2005; Don 2007)), and evidence that the natives are dominated by species like Linepithema humile (Mayr) (Stringer et al. 2009), competition with New Zealand native ant species is unlikely to be a major factor restricting the establishment of invasive ants in New Zealand (Harris undated). Climatic suitability and the extent of human modified habitats are primarily responsible for the distribution of the global invader Linepithema humile (Argentine ant) (Roura-Pascual et al. 2011), including its establishment success within New Zealand (Hartley \& Lester 2003) since first detection in 1990 (Green 1990; Ward et al. 2010).

Although sea containers have long been recognised as a means of entry of exotic ants into New Zealand (Nendick et al. 2006; Ward et al. 2006), the present analysis indicates ant arrival alone or propagule pressure does not necessarily result in establishment. Abiotic factors, such as temperature and rainfall, are likely to be the main contributing factors as to why more tramp ant species successfully establish nests at Napier sea port compared to the Ports of Auckland and Tauranga.

Over the past 10 years the successful eradication of ant incursions at ports and cargo devanning facilities demonstrates the importance of continuing targeted surveillance to achieve early detection. Sites in the wider Napier region that directly receive imported commodities may be more at risk of successful establishment of exotic tramp ant species. Continued vigilance and robust decision making in resourcing surveillance and incursion response activities in these areas is essential to keep New Zealand free of invasive ants.

\section{ACKNOWLEDGEMENTS}

We thank Cath Kingston and Dave Nendick from MPI and Peter Stratford and Lester Mattson from AsureQuality for providing data, and an anonymous reviewer who provided valuable feedback on a draft version of this manuscript. 


\section{REFERENCES}

Ashcroft TT, Nendick D, O'Connor SM, Sarty M, Gunawardana DN, Weston G 2008. Managing the risk of invasive ants establishing in New Zealand. In: Froud KJ, Popay AI, Zydenbos SM ed. Surveillance for Biosecurity: Preborder to pest management. Proceedings of a symposium. The New Zealand Plant Protection Society (Incorporated), Hastings, New Zealand. Pp. 151-160.

Chen Y, Hansen LD, Brown JJ 2002. Nesting sites of the carpenter ant, Camponotus vicinus (Mayr) (Hymenoptera: Formicidae) in Northern Idaho. Environmental Entomology 31: 1037-1042.

Don W 2007. Ants of New Zealand. Otago University Press in association with Otago Museum, Dunedin, New Zealand. 239 p.

Global Invasive Species Database 2005. Solenopsis invicta. http://www.issg.org/ database/ species/ecology.asp?si=77 (accessed 22 April 2013).

Green OR 1990. Entomologist sets new record at Mt. Smart, or Iridomyrmex humilisestablished in New Zealand. The Weta 13: 14-16.

Harris RH, Barker G 2007. Relative risk of invasive ants (Hymenoptera: Formicidae) establishing in New Zealand. New Zealand Journal of Zoology 34: 161-178.

Harris R, undated. Invasive ant risk assessment. http://www. landcareresearch.co.nz /data/ assets/pdf_file/0019/51085/ranking.pdf (accessed 22 April 2013).

Hartley S, Lester PJ 2003. Temperaturedependent development of the Argentine ant, Linepithema humile (Mayr) (Hymenoptera: Formicidae): a degree-day model with implication for range limits in New Zealand. New Zealand Entomologist 26: 91-100.

Hoffman BD, Abbott KL, Davis P 2010. Invasive Ant management. In: Lach L, Parr CL, Abbott KL ed. Ant Ecology. Oxford University Press, Oxford, UK. Pp. 287-304.

Holldobler B, Wilson EO 1990. The Ants. The Belknap Press of Harvard University Press, Cambridge, Massachusetts, USA. Pp. 378-381. Lester PJ 2005. Determinants for the successful establishment of exotic ants in New Zealand. Diversity and Distributions 11:279-288.
Linksvayer TA, Janssen MA 2009. Traits underlying the capacity of ant colonies to adapt to disturbance and stress regimes. Systems Research and Behavioural Science 315: 315-329.

NIWA National Climate database. http://cliflo. niwa.co.nz/ (accessed April 2013).

Nendick D, Sarty M, O'Connor S, Rechenberg G, Skucek R 2006. Pacific offshore container management programme. Biosecurity, a publication of Biosecurity New Zealand. Issue 70: 4-6.

Porter SD 1987. Foraging in Solenopsis invicta (Hymenoptera: Formicidae): Effects of weather and season. Environmental Entomology 16: 802-808.

Porter SD 1988. Impact of temperature on colony growth and development rate of the ant, Solenopsis invicta. Journal of Insect Physiology 34: 1127-1133.

Roura-Pascual N, Hui C, Ikeda T, Leday G, Richardson DM 2011. Relative roles of climatic suitability and anthropogenic influence in determining the pattern of spread in a global invader. Proceedings of the National Academy of Science USA 108: 220-225.

Stringer LD, Stephens AEA, Suckling DM, Charles JG 2009 Ant dominance in urban areas. Urban Ecosystems 12: 503-514.

Stringer LD, Suckling DM, Mattson LTW, Peacock LR 2010. Improving ant-surveillance trap design to reduce competitive exclusion. New Zealand Plant Protection 63: 248-253.

Sarty M, Abbott KL, Lester P 2006. Habitat complexity facilitates coexistence in a tropical ant community. Oecologia 149 (3): 465-473.

Valentine EW, Walker AK 1991. Annotated catalogue of New Zealand Hymenoptera. DSIR Plant Protection Report 4. General Printing Services Ltd, Nelson, New Zealand. $84 \mathrm{p}$.

Vega SJ, Rust MK 2001. The Argentine ant: a significant invasive species in agricultural, urban and natural environments. Sociobiology 37: 3-25.

Vogt JT, Smith WA, Grantham RA, Wright RE 2003. Effects of temperature and season on foraging activity of red imported fire ants (Hymenoptera: Formicidae) in Oklahoma. Environment Entomology 32: 447-451. 
Ward DF 2005. Changes to the classification of ants (Hymenoptera: Formicidae). Weta 30: 16-18

Ward DF 2007. Modelling the potential geographic distribution of invasive ant species in New Zealand. Biological Invasions 9: 723-735.

Ward DF, Beggs JR, Clout MN, Harris RJ, O'Connor S 2006. The diversity and origin of exotic ants arriving to New Zealand via human mediated dispersal. Diversity and Distributions 12: 601-609.
Ward D, Green C, Harris R, Hartley S, Lester P, Stanley M, Suckling D, Toft R 2010. Twenty years of Argentine ants in New Zealand: past research and future priorities for applied management. New Zealand Entomologist 33: 68-78. 